\title{
Understanding the Impact of Land Resource Misallocation on Carbon Emissions in China
}

\author{
Aihui Ma ${ }^{1}$, Yaya $\mathrm{He}^{1,2}$ and Peng Tang ${ }^{1,3, *(\mathbb{D}}$ \\ 1 Department of Land Resource and Real Estate Management, School of Public Administration, \\ Sichuan University, Chengdu 610065, China; aihui.ma@scu.edu.cn (A.M.); heyaya@ccle.cn (Y.H.) \\ 2 Chongqing Country Land Exchange Company Limited, Chongqing 400020, China \\ 3 Center for Social Development and Social Risk Control, Sichuan University, Chengdu 610065, China \\ * Correspondence: tp@scu.edu.cn
}

Citation: Ma, A.; He, Y.; Tang, P. Understanding the Impact of Land Resource Misallocation on Carbon Emissions in China. Land 2021, 10, 1188. https://doi.org/10.3390/ land10111188

Academic Editors: D. Ary

A. Samsura, Erwin van der Krabben and Kristoffer B. Berse

Received: 28 September 2021

Accepted: 2 November 2021

Published: 5 November 2021

Publisher's Note: MDPI stays neutral with regard to jurisdictional claims in published maps and institutional affiliations.

Copyright: (c) 2021 by the authors. Licensee MDPI, Basel, Switzerland. This article is an open access article distributed under the terms and conditions of the Creative Commons Attribution (CC BY) license (https:/ / creativecommons.org/licenses/by/ $4.0 /)$.

\begin{abstract}
In order to achieve growth in fiscal revenue and the regional economy under the Chinese decentralization system, the land resources misallocation (LRM) among different industries was promoted through the differentiated land supply strategy, which has a vital role in carbon emissions. This study theoretically analyzes the overall effect and the effect of the intermediate LRM mechanism on carbon emissions and empirically tests the impact of LRM on carbon emissions based on panel data collected from 30 provinces in China from 2005 to 2017 using the environmental Kuznets curve theory. The results show that (1) the local governments have monopolized the primary land market across the nation, leading to resource misallocation among industrial, commercial, and residential land. This inefficient and unsustainable allocation aggravated the release of carbon emissions. (2) The impact of LRM on carbon emissions has varied among different regions. LRM in the eastern and central regions significantly exacerbated carbon emissions. A greater impact on carbon emissions occurred in the eastern region, while the impact was insignificant in the western region. (3) There are two mechanisms through which LRM affects carbon emissions. One is the restraint of upgrading industrial structure, and the other is the restriction of technological innovations. In conclusion, speeding up the reform of the tax sharing system is suggested to reduce the excessive dependence of local governments on land resources. Meanwhile, in order to reduce carbon emissions, the land acquisition and transfer system should be reformed to gradually achieve the market-oriented allocation of land resources, and the benefits coordination mechanism of different land transfer modes should be established. Finally, we propose different carbon emission reduction policies for the heterogeneity of regional economic development.
\end{abstract}

Keywords: land resource allocation; carbon emission; fiscal decentralization; environmental Kuznets curve

\section{Introduction}

High consumption of fossil fuels in producing energy has brought about disastrous and irreversible environmental impacts associated with global climate change, posing a huge threat to the world's sustainable development and preservation of natural resources [1-3]. In order to cope with the challenge of global warming, the reduction in carbon emissions has become a hot topic of global development and has raised wide concern among the international community [4-6]. China has embraced rapid economic development since the reform and market opening-up, which inevitably induced the rapid growth of fossil fuel combustion and the release of carbon emissions [7,8]. Although China has adjusted the economic and industrial structures to release fewer carbon emissions since the supply side reform started in 2015, the ideal level of carbon emissions may take some time to reach due to the extensive development mode and unreasonable industrial structure [9]. The increasing carbon emissions in China not only impede the sustainable 
development of the social economy but also induce global climate change [10]. As a responsible power, China has undertaken a series of emission reduction measures with obvious effects, including setting emission reduction targets [11,12], signing the "Kyoto Protocol" in 1998 and approved in 2002, and reducing the energy consumption intensity of provinces [13]. According to the "China-US Joint Announcement on Climate Change" in 2014, carbon emissions should peak and begin to decline in $2030[14,15]$. These initiatives show the determination and pathway of the Chinese government to pursue "low-carbon" development.

Most of the existing literature discusses the determinants of carbon emissions in terms of the energy consumption structure and intensity, economic growth, industrial structure, urbanization, technological innovation, foreign direct investment, and local government behavior. Given that land is a scarce resource and an essential production factor associated with economic development, reasonable land allocation is crucial for economic development and the carbon emission intensity [15]. It has been found that carbon emissions caused by a change in land use account for a high proportion of total carbon emissions, as much as one-third in 1850-1998 [16]. The existing literature has focused on different aspects related to the impact of land use change on carbon emissions. Some studies have focused on the impacts of land use changes on ecosystem carbon storage or soil carbon flux [17-19], finding that the conversion of cultivated land to construction use will reduce ecological carbon storage [20]. Second, some papers have studied the effects of land use changes related to carbon emissions, including land use carbon budget accounting [21-23], the carbon emission effect assessment of land use planning schemes [24,25], and the driving factors and factor decomposition related to land use carbon emissions [26-28]. The third research aspect is the evaluation of the carbon effect of land use engineering projects and low-carbon optimization $[29,30]$. Finally, some studies have explored the carbon emission efficiency and carbon emission reduction potential of land use [31-34].

These studies have mainly explored the carbon emissions brought about by changes in the allocation of land resources from the perspective of natural changes, while political and economic institutional arrangements behind the allocation of land resources by local governments have been ignored. Under the decentralized Chinese system, the impacts of land allocation and utilization on carbon emissions are mainly attributable to the strong land supply motivation of local governments in the pursuit of fiscal revenue and GDP growth. A top priority for land use has been given to the manufacturing industry, which can bring more revenue and GDP to the local government [35-38]. In order to attract investment, industrial land is transferred at a "low price", "zero price", or even "negative price", while the "hungry land policy" is adopted by the government to increase the sales prices of commercial and residential land [35-40]. The extensively used industrial land and barren and idle industrial parks are in sharp contrast to commercial land areas with small supply scales and high prices [41]. Thus, investigating the mechanisms by which LRM impacts carbon emissions is significant.

Using the framework of Chinese decentralization, this article focuses on the following three problems: (1) the impact of LRM on carbon emissions; (2) the specific mechanism associated with the carbon emissions effect of LRM; (3) the differences in the influence of LRM in regions with different levels of economic development. In contrast with existing research, this paper addresses two main issues. First, it innovatively considers the mechanism affecting carbon emissions from the perspective of resource allocation and provides a new perspective for the government to optimize the allocation of land resources and reduce carbon emissions. Second, the introduction of industrial structure upgrades and technological innovations as intermediary variables of LRM that affect carbon emissions is used to theoretically explain its mechanism and expand the research on the impacts of local government behaviors on carbon emissions. 


\section{Background and Theoretical Hypothesis}

\subsection{Institutional Background}

Chinese decentralization, characterized by economic decentralization and political centralization, has an important impact on the allocation of land resources by local governments [42,43]. Regarding the influence of economic decentralization, the reform of the tax sharing system in 1994, as the proxy of economic decentralization, changed the financial revenue and expenditure structure of the central and local governments, shaping a pattern of fiscal decentralization with a "strong trunk and weak branches" [44,45]. The ever-widening fiscal gap has forced local governments to seek extra-budgetary revenue. As a core revenue resource for local governments, land granting has become an important tool used by local governments to relieve financial pressure. As part of the monopolization of the land acquisition market and the primary land market, local governments have adopted high-price and limiting-supply strategies for commercial and residential land to obtain more land granting revenue. Meanwhile, in order to pursue value-added tax and expand the tax base, the best strategy for local governments is to sell large amounts of industrial land at low prices to attract investment [35-40]. Therefore, "Growing money with the land" is considered to be an important result of fiscal decentralization.

Political centralization is mainly manifested by the fact that the central government (senior government) has the primary power to appoint, remove, and promote officials from the local government (junior government) through a performance evaluation index system [35-37,46]. In China, the performance evaluation system based on economic development indicators results in a "promotion tournament", "GDP tournament", and other unique phenomena $[36,46]$. As economic growth relies on investment and the price of industrial land affects the cost of factors related to enterprise, local governments prioritize the low-price transfer of industrial land to attract investment and use non-mobile urban land elements to attract mobile capital and labor to drive the economic development of the jurisdiction. At the same time, the manufacturing industry promotes housing prices through spillover effects, which helps the local government to obtain fiscal revenue [35-40,47]. The resulting financial guarantee benefits regional infrastructure construction and lays the foundation for attracting investment; that is, "attracting capital from the land" is closely related to political centralization.

In the context of China's unique decentralization system, the local government's differentiated supply strategy for different uses of land was formed. The best strategy for local governments is to sell large amounts of industrial land at low prices and, at the same time, to sell commercial and residential land at high prices, thus jointly promoting the development of China's urbanization and industrialization [35-40,47,48]. However, this strategy has caused scale mismatch and price distortion between industrial land and commercial and residential land, reducing the efficiency of land use and causing distortions in the allocation of land resources, [35-40,49]. The misallocation of land resources hinders the improvement of enterprise land use efficiency, inhibits the enterprise innovation, and reduces the living environment quality. It also leads to the formation of the industry structure dominated by low-end manufacturing industries. These impacts further cause problems such as repeated industrial construction and the suppression of industrial structure upgrading, which, in turn, makes the environmental pollution problem more serious [35-40,48-52]. Therefore, the essence of the effect of LRM is the distortion of the factor market, which has affected the industrial structure and technological innovation and, thus, has affected carbon emissions.

\subsection{Land Resource Misallocation, Industrial Structural Upgrade, and Carbon Emissions}

The main mechanisms associated with LRM to restrain the upgrading of industrial structures are as follows: on the one hand, in order to stand out in the "promotional championship", local governments have adopted a "competitive" strategy, that is, a low-price and large-scale transfer of industrial land, lower industrial entry barriers, and a bottomline focus on investment quality to attract enterprises to invest. As local governments 
tend to attach importance to the scale rather than the quality of investment promotion, a large number of low-end manufacturing industries have entered the market, resulting in a low-level, repetitive, and homogenous industrial structure [53,54]. The excessive distortion of profit rate inhibits the upgrade of industrial structure and strengthens the structural rigidity of middle- and low-end manufacturing industries with high levels of carbon emissions [55]. On the other hand, to make up for the loss of low-cost industrial land transfer, local governments tend to limit the supply scale of commercial land and increase its price, which has caused a crowding-out effect for the services industry $[35,36,56]$. Thus, the large-scale agglomeration of low-end manufacturing has hindered the transformation of the industrial structure from labor and capital-intensive to knowledge- and technologyintensive industries, which is not conducive to the transformation and upgrading of the industrial structure.

As it is closely related to the variety and quantity of resources consumed in the production process, the industrial structure determines the utilization efficiency of resources [35,57], thus affecting regional carbon emissions. Manufacturing, especially heavy industries, is an energy-intensive industry and the main body responsible for energy consumption and carbon emissions. In contrast, the tertiary industry is dominated by knowledge-intensive and technology-intensive industries, which consume less energy and emit fewer carbon emissions [58]. Therefore, our first hypothesis is that LRM is not conducive to the development of a low-carbon economy as it restrains the upgrading of the industrial structure.

\subsection{Land Resource Misallocation, Technological Innovation, and Carbon Emissions}

LRM hinders technological innovation in the following three ways. First, the misallocation of land resources has increased the profits of real-estate-related industries, leading a large number of credit funds and corporate funds to be invested in the real estate industry, thereby squeezing out innovative R\&D investment funds. Meanwhile, compared with the real economy, such as manufacturing and agriculture, the technological innovation capabilities of real estate are lower [59], which reduces the innovation capability of the entire industrial economy. Second, the misallocation of land resources is associated with high housing prices, increasing the cost of living for residents and reducing the utility levels of producers and consumers [60,61], which is not conducive to the inflow of labor. Additionally, cities with higher housing prices often hinder the regional agglomeration effect and the improvement of innovation performance [38,62]. In addition, with limited family resources and traditional concepts, high housing prices will inhibit higher-risk innovative and entrepreneurial activities [63]. Third, the misallocation of land resources can easily lead to rent-seeking, which restricts the improvement of enterprises' innovation capabilities. In the context of land monopoly supply and a lack of regulatory mechanisms, local governments can autonomously control the scale and price of land supply, which can easily breed corruption and land violations $[35,37,64]$. If companies focus on government rent-seeking instead of using their talents in management and innovation, the market regulations will be undermined, and the development of corporate innovation activities will be hindered. The non-marketization of the economic system will result in rent-seeking self-reinforcement, which will not only crowd out the innovation funds of enterprises but also result in insufficient motivation for innovation across the entire society $[40,65]$.

Technological innovation is of great significance for the reduction in regional carbon emissions. Numerous studies have shown that the difference in technological innovation between regions is the key factor associated with differences in energy use efficiency and is an important means for reducing carbon emissions [66,67]. General technological innovation can improve land resource utilization efficiency, energy utilization efficiency, labor productivity, and reduce carbon emissions per unit GDP. Environmentally friendly technological innovations allow for the replacement of high-energy-consumption and highly polluting technological equipment with low-energy-consumption and low polluting equipment [34], reducing regional carbon emissions to a certain extent. 
In summary, our second hypothesis is that LRM is not conducive to the reduction in carbon emissions as it restrains technological innovation by enterprises.

\section{Model and Data}

\subsection{Model Settings}

Based on the environmental Kuznets curve (EKC) model proposed by Grossman and Kruger [68], we constructed a basic model to introduce land resource misallocation, as follows:

$$
L C E_{i t}=\beta_{0}+\beta_{1} L R M_{i t}+\beta_{2} L E_{i t}+\beta_{3} L E_{i t}^{2}+\gamma_{i t} \sum_{j=1}^{n} X_{j i t}+\varepsilon_{i t}
$$

where subscripts $i$ and $t$ refer to the region and year, respectively. The dependent variable $L C E_{i t}$ represents the total carbon emissions, $L R M_{i t}$ refers to the land resource misallocation, $L E_{i t}$ represents the economic growth level, and $L E_{i t}{ }^{2}$ is used to verify whether there is a non-linear relationship between economic growth and environmental pollution. $\sum_{j=1}^{n} X_{j i t}$ is a set of control variables, where $j$ represents the number of control variables, and $\varepsilon_{i t}$ is the error term.

\subsection{Specification of Variables}

We selected total carbon emissions as the explained variable and calculated its value based on reference methods recommended by the Intergovernmental Panel on Climate Change (IPCC, 2006) in the "Guidelines for National Greenhouse Gas Inventories" [1]. The following eight main energy varieties were measured: coal, coke, crude oil, gasoline, kerosene, diesel, fuel oil, and natural gas. The emission coefficient values of the energy varieties are shown in Table 1. The calculation method used was as follows:

$$
L C E=\sum_{k=1}^{8} L C E_{k}=\sum_{k=1}^{8} E_{k} \times S C_{k} \times C F_{k}
$$

where $L C E$ is the total carbon emissions, $K$ is the energy type, $E$ is energy consumption, $S C$ refers to the standard coal conversion coefficient, and $C F$ is the carbon emissions coefficient.

Table 1. The calculation coefficient for various energy varieties.

\begin{tabular}{ccccccccc}
\hline Variety of Energy & Coal & Coke & Crude & Oil & Gasoline & Kerosene & Diesel & Fuel \\
\hline Conversion standard coal coefficient & 0.7143 & 0.9714 & 1.4286 & 1.4714 & 1.4714 & 1.4571 & 1.4286 & 1.3300 \\
Carbon emissions coefficient & 0.7559 & 0.855 & 0.5857 & 0.5538 & 0.5714 & 0.5921 & 0.6185 & 0.4226 \\
\hline
\end{tabular}

Note: units used for the standard coal coefficient: $\mathrm{kg} / \mathrm{m}^{3}$ for natural gas, tce $/ \mathrm{t}$ for the rest.

Regarding the core explanatory variable, the following four main dimensions can be used to identify the misallocation of land resources: agricultural land and construction land, land indicators among different cities, the urban construction land reserve in different industries, and the land resources of industrial enterprises in cities $[69,70]$. Considering that carbon emissions are related to industries, this study mainly measured the misallocation degree of land resources in different industries and for different purposes, that is, the urban construction land area in different industries. As local governments have a monopoly in the primary land market, they can affect the supply scale and price of different uses of land. Low prices and the excessive transfer of industrial land will seriously underestimate the price of industrial land, resulting in a serious waste of scarce land resources. While the land-hungry strategy to raise the price of residential and commercial land and "horizontally subsidize" the loss of industrial land at a low price will lead to high housing prices, increase the living cost of urban residents, and reduce the land use efficiency, the nature of extensive and inefficient use of land resources is resource misallocation [71,72]. Due to the lack of corresponding micro-statistical data, land resource misallocation cannot be quantitatively measured according to the marginal output of construction land for different purposes. Therefore, scholars select representative indicators and adopt indirect methods to measure 
land resource misallocation [73]. Most previous studies regarded "negotiated transfer" as a synonym of "industrial land" and "low-price transfer" [74], where the larger the proportion of negotiated transfer is in a region, or the larger the scale of industrial land transfer is in this region, and the greater the misallocation degree of land resources is. That is, the ratio of the agreed and total leased areas is used to quantify land resource misallocation. At the end of 2006, the State Council promulgated and implemented the "Circular of the State Council on Intensifying the Land Control", stipulating that industrial land must be transferred through bidding, auction, and listing. This policy led to a rapid decline in the proportion of negotiated transfers of industrial land after 2008. Referring to the research of some scholars, we used the proportion of negotiated transfer area to the transfer area of state-owned construction land to measure the degree of land misallocation from 2003 to 2008. We used the proportion of the industrial and mining storage land supply area to the transfer area of state-owned construction land to measure the degree of land misallocation from 2009 to 2017 [35-40,69].

For the control variables, based on existing research [6-9,11-34], the impacts of seven indicators-economic growth, population, urbanization, industrial structure, science and technology level, fixed-asset investment, and foreign direct investment (FDI)—on the direction and extent of regional carbon emissions were explored. We also added the quadratic term economic growth to verify the Kuznets curve hypothesis. In order to eliminate the effect of heteroscedasticity, all the variables used are presented as logarithms. All the variables are shown in Table 2.

Table 2. Connotations of the variables.

\begin{tabular}{|c|c|c|}
\hline Variable Type & Variable Name & Calculation Methods (All Natural Logarithm) \\
\hline \multirow[t]{3}{*}{ Explained variable } & Carbon emissions (LCE) & Total carbon emissions \\
\hline & Carbon emissions intensity (LCI) & Total carbon emissions/GDP \\
\hline & & $\begin{array}{l}\text { Negotiated transfer area/total construction land transfer } \\
\text { area (2005-2008) }\end{array}$ \\
\hline \multirow{5}{*}{ Core explanatory variable } & Land resource misallocation (LKIM) & $\begin{array}{l}\text { Industrial and mining storage transfer area/total } \\
\text { construction land transfer area (2009-2017) }\end{array}$ \\
\hline & Economic growth (LE) & GDP per capita \\
\hline & Economic growth squared $\left(\mathrm{LE}^{2}\right)$ & GDP per capita squared \\
\hline & Population size (LP) & Total population \\
\hline & Urbanization (LURB) & Urban population/total population \\
\hline \multirow[t]{4}{*}{ Control variables } & Industrial structure (LIND) & Added value of the secondary industry/GDP \\
\hline & Scientific and technological level (LT) & $\begin{array}{c}\text { The number of inventions in the authorized number of } \\
\text { three domestic patent applications }\end{array}$ \\
\hline & Fixed-asset investment (LPFI) & Total investment in fixed assets / total population \\
\hline & Foreign direct investment (LPFDI) & Actual use of foreign investment/total population \\
\hline
\end{tabular}

\subsection{Data Collection}

Due to a lack of data on carbon emissions in prefecture-level cities, panel data from 30 provinces (excluding Tibet, Hong Kong, Macao, and Taiwan) in China collected from 2005 to 2017 were used. Data on LRM were collated from the "China Land and Resources Statistical Yearbook (2006-2018)". Data on carbon emissions were obtained from the "China Energy Statistical Yearbook (2006-2018)". Data on foreign direct investment were acquired from the "China City Statistical Yearbook (2006-2018)", and data on the remaining variables were obtained from the "China Statistical Yearbook (2006-2018)". The descriptive statistics for the analyzed data are illustrated in Table 3. 
Table 3. Descriptive statistics of each variable.

\begin{tabular}{|c|c|c|c|c|c|}
\hline Variable Name & Unit & Mean & Std. Dev. & Min. & Max. \\
\hline$L C E$ & Ten thousand tons & $10,137.43$ & 7175.44 & 446.92 & $40,184.93$ \\
\hline LCI & Tons/ten thousand yuan & 8799.85 & 5957.42 & 1226.59 & $37,745.19$ \\
\hline LRM & $\%$ & 35.13 & 18.89 & 0.63 & 91.47 \\
\hline LE & Yuan & $36,820.61$ & $22,790.81$ & 5052 & 118,198 \\
\hline $\mathrm{LE}^{2}$ & Yuan & $1.87 \times 10^{9}$ & $2.41 \times 10^{9}$ & $2.55 \times 10^{9}$ & $1.4 \times 10^{10}$ \\
\hline LP & Ten thousand people & 4438.36 & 2663.31 & 543 & 10,999 \\
\hline LURB & $\%$ & 52.38 & 14.03 & 26.86 & 89.61 \\
\hline LIND & $\%$ & 46.85 & 7.90 & 19.26 & 59.05 \\
\hline LT & Item & 3699.03 & 6451.28 & 23 & 40,952 \\
\hline LPFI & Ten thousand yuan/person & 2.44 & 1.55 & 0.27 & 8.18 \\
\hline LPFDI & Ten thousand yuan/person & 0.11 & 0.14 & 0 & 1.37 \\
\hline
\end{tabular}

\section{Results and Discussion}

\subsection{Basic Estimation Results}

To avoid spurious regressions, it is usually necessary to test the stationarity of the panel data. Given that short-term panel data were used in this paper, the Hausman test (HT) was adopted. The results of the HT show that all the variables passed the significance test; that is, the variables were deemed to be stationary. Based on the results of the HT, the fixed effect model was determined to be better than the random effect model. The results of the fixed effect model and the random effect model are shown in Table 4.

Table 4. The impacts of LRM on carbon emissions at the national level.

\begin{tabular}{|c|c|c|c|c|}
\hline & Model 1 (FE) & Model 1 (RE) & Model 2 (FE) & Model 2 (RE) \\
\hline LRM & $\begin{array}{c}0.0336^{* * *} \\
(3.01)\end{array}$ & $\begin{array}{c}0.0340^{* * *} \\
(3.04)\end{array}$ & $\begin{array}{c}0.0330^{* * * *} \\
(3.08)\end{array}$ & $\begin{array}{c}0.0355^{* * * *} \\
(3.26)\end{array}$ \\
\hline LE & $\begin{array}{c}1.2621^{* * * *} \\
(4.16)\end{array}$ & $\begin{array}{c}1.2782 * * * \\
(4.21)\end{array}$ & $\begin{array}{c}1.47528^{* * *} \\
(4.13)\end{array}$ & $\begin{array}{c}1.7685^{* * * *} \\
(4.44)\end{array}$ \\
\hline $\mathrm{LE}^{2}$ & $\begin{array}{c}-0.0418^{* * *} \\
(-2.81)\end{array}$ & $\begin{array}{c}-0.0426^{* * *} \\
(-2.86)\end{array}$ & $\begin{array}{c}-0.0680^{* * * *} \\
(-3.4)\end{array}$ & $\begin{array}{c}-0.0683^{* *} \\
(-3.72)\end{array}$ \\
\hline LP & & & $\begin{array}{c}0.4749^{* *} \\
(2.23)\end{array}$ & $\begin{array}{c}0.7142^{* * *} \\
(7.89)\end{array}$ \\
\hline LURB & & & $\begin{array}{c}-0.5384^{* * *} \\
(-2.88)\end{array}$ & $\begin{array}{c}-0.3288 \text { * } \\
(-1.92)\end{array}$ \\
\hline LIND & & & $\begin{array}{c}0.2349^{* * * *} \\
(3.03)\end{array}$ & $\begin{array}{c}0.2885^{* * * *} \\
(3.78)\end{array}$ \\
\hline LT & & & $\begin{array}{c}0.0200 \\
(0.73)\end{array}$ & $\begin{array}{c}0.0020 \\
(0.07)\end{array}$ \\
\hline LPFI & & & $\begin{array}{c}0.1142^{* * * *} \\
(2.75)\end{array}$ & $\begin{array}{c}0.0921^{* *} \\
(2.29)\end{array}$ \\
\hline LPFDI & & & $\begin{array}{c}-0.0602 * * * \\
(-5.03)\end{array}$ & $\begin{array}{c}-0.0588^{* * *} \\
(-4.87)\end{array}$ \\
\hline $\mathrm{R}^{2}$ & 0.7376 & 0.7376 & 0.7763 & 0.7749 \\
\hline F/Wald & $334.55^{* * *}$ & $1001.30^{* * *}$ & $135.37^{* * *}$ & $1244.61^{* * *}$ \\
\hline Hausman test & \multicolumn{2}{|c|}{$3.77^{* * *}$} & \multicolumn{2}{|c|}{$27.47^{* * *}$} \\
\hline $\mathrm{N}$ & 390 & 390 & 390 & 390 \\
\hline
\end{tabular}

According to the estimation results for Model one, the LRM passed the significance level test at the 1\% level, indicating a positive correlation between LRM and total carbon emission production. The results show that each unit of LRM increases the total carbon emissions by 0.0336 units. Model two was obtained by adding control variables. The coefficient of LRM was 0.0330 and was significant at the $1 \%$ level, indicating that LRM significantly aggravates carbon emissions. 
Both LE and LE ${ }^{2}$ passed the significance test, and the coefficient of LE was found to be positive, while the coefficient of $\mathrm{LE}^{2}$ was found to be negative, indicating that the GDP per capita and the carbon emissions production have an inverted U-shaped relationship. As the results for Model two are consistent with those obtained with Model one, we argue that these findings verify the EKC hypothesis.

Both the population size (LP) and urbanization level (LURB) passed the significance test at the $1 \%$ level, with coefficients of 0.4749 and -0.5384 , respectively. This indicates that although an increase in the total population will increase carbon emissions, the scale effect and agglomeration effect of urbanization can improve urban infrastructure and services, promoting the reduction in energy consumption. The coefficient of the industrial structure (LIND) was found to be 0.2349 , and this was significant at the $1 \%$ level, indicating that the higher the proportion of the output value of the secondary industry is in terms of the GDP, the more industries there will be with a high energy consumption, high levels of emissions, and low efficiency, and the stronger the dependence on energy and the higher the level of carbon emissions will be. The result is consistent with the findings of Zhang, and it verifies the industrial structure as being one of the driving factors for China's carbon emission growth [75]. The coefficient of the science and technology level (LT) was found to be 0.0200 , but no significance was shown. We expect that the level of science and technology will reduce carbon emissions by improving the efficiency of energy utilization. However, the results show that the level of science and technology in China has not significantly improved the efficiency of resource use. The coefficient of fixed-asset investment (LPFI) was found to be positive and significant at the $1 \%$ level, indicating that the extensive economic development mode driven by investment will promote an increase in carbon emissions. The coefficient of LPFDI was found to be -0.0602 , which passed the significance test at the $1 \%$ level, indicating that foreign investment has reduced carbon emissions. Theoretically, foreign investment has "pollution heaven" and "pollution halo" effects on carbon emissions. On the one hand, foreign investment transfers heavily polluting industries to developing countries to avoid environmental regulations, thus increasing the local carbon emission level. On the other hand, foreign investment has a higher technological level than local enterprises, which will reduce carbon emissions [76]. The results show that foreign direct investment has a "pollution halo" effect on carbon emissions.

\subsection{Regional Differences}

According to the general division of the National Statistical Bureau and the most related research $[77,78]$, this paper divided 30 provinces into three major regions. The eastern region included 11 provinces (Beijing, Tianjin, Hebei, Liaoning, Shanghai, Jiangsu, Zhejiang, Fujian, Shandong, Guangdong, and Hainan). The central region included eight provinces (Shanxi, Jilin, Heilongjiang, Anhui, Jiangxi, Henan, Hubei, and Hunan), and the western region included 11 provinces (Inner Mongolia, Guangxi, Sichuan, Chongqing, Guizhou, Yunnan, Shaanxi, Gansu, Qinghai, Ningxia, and Xinjiang). We further explored the impact of LRM on carbon emissions by region. The regional regression results are shown in Table 5.

The HT results presented in Table 5 show that the fixed effect model worked better for our data. Thus, we mainly report the results of the fixed effect model, as shown in columns one, three, and five. The impact coefficients of LRM were found to be positive in all three regions. Specifically, the coefficient of the impact of LRM on carbon emissions in the Eastern and Central regions was 0.0230 and 0.0225 , respectively, with both values being significant, while the impact of LRM on carbon emissions in the Western region was not significant. This difference may be related to the differences in the degree of land development and stage of development between regions. Local governments in the eastern and central regions pay more attention to the scale rather than the quality of the investment attracted, as this promotes political performance. This leads to the "bottom line for attracting investment" effect being more prominent than in western China; that is, the impact of LRM on carbon emissions is more pronounced in the eastern and central regions. 
Table 5. The impact of LRM on carbon emissions by region.

\begin{tabular}{|c|c|c|c|c|c|c|}
\hline & $\begin{array}{c}\text { Eastern } \\
\text { Regions } \\
(\mathrm{FE}) /(1)\end{array}$ & $\begin{array}{l}\text { Eastern } \\
\text { Regions } \\
(\mathrm{RE}) /(2)\end{array}$ & $\begin{array}{c}\text { Central } \\
\text { Regions } \\
(\mathrm{FE}) /(3)\end{array}$ & $\begin{array}{l}\text { Central } \\
\text { Regions } \\
(\mathrm{RE}) /(4)\end{array}$ & $\begin{array}{c}\text { Western } \\
\text { Regions } \\
(\mathrm{FE}) /(5)\end{array}$ & $\begin{array}{l}\text { Western } \\
\text { Regions } \\
\text { (RE)/(6) }\end{array}$ \\
\hline LRM & $\begin{array}{c}0.0230 \text { * } \\
(1.82)\end{array}$ & $\begin{array}{l}0.0280^{* * *} \\
(3.04)\end{array}$ & $\begin{array}{c}0.0225^{* *} \\
(2.55)\end{array}$ & $\begin{array}{l}0.0602 \\
(1.21)\end{array}$ & $\begin{array}{l}0.0284 \\
(1.24)\end{array}$ & $\begin{array}{l}0.0218 \\
(0.83)\end{array}$ \\
\hline LE & $\begin{array}{l}5.1111^{* * *} \\
(7.31)\end{array}$ & $\begin{array}{l}3.7806^{* * *} \\
(2.90)\end{array}$ & $\begin{array}{c}4.9367^{* * * *} \\
(8.25)\end{array}$ & $\begin{array}{l}7.9190 * * * \\
(2.65)\end{array}$ & $\begin{array}{l}0.1650 \\
(0.22)\end{array}$ & $\begin{array}{l}-1.0626 \\
(-1.39)\end{array}$ \\
\hline $\mathrm{LE}^{2}$ & $\begin{array}{c}-0.2159 * * * \\
(-6.62)\end{array}$ & $\begin{array}{c}-0.1398^{* *} \\
(-2.39)\end{array}$ & $\begin{array}{c}-0.2223 * * * \\
(-7.88)\end{array}$ & $\begin{array}{c}-0.3423 \text { ** } \\
(-2.35)\end{array}$ & $\begin{array}{l}0.0084 \\
(0.24)\end{array}$ & $\begin{array}{l}0.0716^{* *} \\
(2.03)\end{array}$ \\
\hline LP & $\begin{array}{c}0.6137^{* *} \\
(2.39)\end{array}$ & $\begin{array}{c}1.3941^{* * *} \\
(14.65)\end{array}$ & $\begin{array}{l}0.4727 \\
(1.13)\end{array}$ & $\begin{array}{l}0.0307 \\
(0.12)\end{array}$ & $\begin{array}{l}2.0113^{* * * *} \\
(3.47)\end{array}$ & $\begin{array}{c}0.5490 * * * \\
(3.96)\end{array}$ \\
\hline LURB & $\begin{array}{l}0.1485 \\
(0.48)\end{array}$ & $\begin{array}{c}0.5981^{* *} \\
(2.08)\end{array}$ & $\begin{array}{c}-0.4649^{* * *} \\
(-3.14)\end{array}$ & $\begin{array}{c}-1.7198 \text { *** } \\
(-2.79)\end{array}$ & $\begin{array}{c}-2.2334^{* * *} \\
(-5.08)\end{array}$ & $\begin{aligned}- & 1.9086^{* * * *} \\
& (-4.41)\end{aligned}$ \\
\hline LIND & $\begin{array}{c}0.4080^{* * *} \\
(2.63)\end{array}$ & $\begin{array}{c}0.6428^{* * *} \\
(5.01)\end{array}$ & $\begin{array}{l}-0.0563 \\
(-0.97)\end{array}$ & $\begin{array}{l}-0.1441 \\
(-0.54)\end{array}$ & $\begin{array}{c}0.3735^{* *} \\
(2.10)\end{array}$ & $\begin{array}{l}0.2940 \\
(1.62)\end{array}$ \\
\hline LT & $\begin{array}{l}-0.0326 \\
(-0.81)\end{array}$ & $\begin{array}{c}-0.3587^{* * * *} \\
(-6.46)\end{array}$ & $\begin{array}{c}0.0751^{* * *} \\
(3.03)\end{array}$ & $\begin{array}{c}0.0672 \\
(0.63)\end{array}$ & $\begin{array}{l}0.0679 \\
(1.36)\end{array}$ & $\begin{array}{l}0.0048 \\
(0.09)\end{array}$ \\
\hline LPFI & $\begin{array}{l}-0.0204 \\
(-0.37)\end{array}$ & $\begin{array}{l}0.1221 \\
(1.60)\end{array}$ & $\begin{array}{c}-0.1306^{* * *} \\
(-3.14)\end{array}$ & $\begin{array}{c}0.2147 \\
(1.2)\end{array}$ & $\begin{array}{c}0.3386^{* * *} \\
(3.34)\end{array}$ & $\begin{array}{l}0.0921 \text { ** } \\
(2.29)\end{array}$ \\
\hline LPFDI & $\begin{array}{l}-0.0477 * \\
(-1.93)\end{array}$ & $\begin{array}{l}-0.0378 \\
(-0.89) \\
\end{array}$ & $\begin{array}{c}0.0001 \\
(0.01)\end{array}$ & $\begin{array}{c}-0.6403^{* * *} \\
(-7.95)\end{array}$ & $\begin{array}{l}-0.0061 \\
(-0.39)\end{array}$ & $\begin{array}{c}0.3766^{* * *} \\
(3.48)\end{array}$ \\
\hline $\mathrm{R}^{2}$ & 0.8500 & 0.7499 & 0.9214 & 0.8484 & 0.8574 & 0.8448 \\
\hline F/Wald & $77.46^{* * *}$ & $1409.39 * * *$ & 113.32 & 155.71 & $82.17^{* * *}$ & $570.07^{* * *}$ \\
\hline Hausman test & \multicolumn{2}{|c|}{$66.33^{* * *}$} & \multicolumn{2}{|c|}{$103.54^{* * *}$} & \multicolumn{2}{|c|}{$951.41^{* * *}$} \\
\hline $\mathrm{N}$ & 143 & 143 & 104 & 104 & 143 & 143 \\
\hline
\end{tabular}

Note: the data in the table excluding parentheses are coefficients; $t$ values are presented in parentheses, ${ }^{*}, * *$, and ${ }^{* * *}$ represent significance at 10,5 , and $1 \%$ levels, respectively; FE(RE) stands for fixed(random) effects model.

The first and second terms of GDP per capita (LE and $\mathrm{LE}^{2}$ ) passed the significance test in the eastern and central regions, and the negative coefficient of the quadratic term showed a significant inverted U-shaped relationship between the GDP per capita and the carbon emissions produced. In contrast, in the western region, the coefficient was not significant. Regarding the different impacts of control variables, in the eastern region, the population size (LP) and industrial structure (LIND) were shown to promote an increase in carbon emissions significantly, and foreign direct investment (LPFDI) was associated with reduced carbon emissions. In the central region, the sci-tech level (LT) was shown to stimulate carbon emissions, while urbanization (LURB) and the level of investment in fixed assets (LPFI) were associated with decreases in the level of carbon emissions. In the western region, the population size (LP), industrial structure (LIND), and investment in fixed assets (LPFI) were found to have significant positive relationships with carbon emissions, while the rate of urbanization (LURB) was found to be conducive to the reduction in carbon emissions.

\subsection{Intermediate Mechanism}

Based on the theoretical analysis, two variables were selected to explore the internal mechanisms of the impact of LRM on carbon emissions. One was the intermediate mechanism related to industrial structure upgrading, and the other was technological innovation.

Regarding the upgrading of industrial structure, this study constructed a hierarchical index of an industrial structure to represent the advanced level of the industrial structure. 
This was achieved by referring to the practices of $\mathrm{Li}$ and Luo [27]. The specific calculation formula used was as follows:

$$
\text { IS }=\sum_{i=1}^{3} I_{i} \times i=I_{1} \times 1+I_{2} \times 2+I_{3} \times 3
$$

where $I_{i}$ represents the proportion of the output value of industry $i$ to the GDP. A larger value indicates a more advanced regional industrial structure. In order to eliminate the influence of heteroscedasticity, the natural logarithm was adopted (LIS).

For the measurement of technological innovation, the index of government expenditure on science and technology (LSTE) was selected. Then, the mediation effect model was applied, and the regression results are shown in Table 6.

Table 6. Results for the intermediate model.

\begin{tabular}{|c|c|c|c|c|}
\hline Variables & LIS & LSTE & $L C E$ & $L C E$ \\
\hline LRM & $\begin{array}{c}-0.0123 \text { ** } \\
(-2.54)\end{array}$ & $\begin{array}{c}-0.6447^{* * *} \\
(-9.20)\end{array}$ & $\begin{array}{c}0.0349 * * * \\
(3.13)\end{array}$ & $\begin{array}{c}0.0447^{* * *} \\
(4.36)\end{array}$ \\
\hline LE & & & $\begin{array}{c}1.0744^{* * *} \\
(3.38)\end{array}$ & $\begin{array}{c}1.0634^{* * *} \\
(2.73)\end{array}$ \\
\hline $\mathrm{LE}^{2}$ & & & $\begin{array}{c}-0.0312 * * * \\
(-1.97)\end{array}$ & $\begin{array}{c}-0.0329 * \\
(-1.72)\end{array}$ \\
\hline LIS & & & $\begin{array}{c}-0.8110 * \\
(-1.90)\end{array}$ & \\
\hline LSTE & & & & $\begin{array}{c}-0.0266^{* * *} \\
(-3.12)\end{array}$ \\
\hline $\mathrm{R}^{2}$ & 0.1148 & 0.2110 & 0.7403 & 0.6580 \\
\hline $\mathrm{N}$ & 360 & 360 & 360 & 360 \\
\hline
\end{tabular}

Note: the data in the table excluding parentheses are coefficients; $t$ values are presented in parentheses; ${ }^{*},{ }^{* *}$, and *** represent significance at the 10,5 , and $1 \%$ levels, respectively.

As shown in Table 6, LRM was found to have a significant negative effect on industrial structure upgrading (LIS) and technological innovation (LSTE), with coefficients of -0.0123 and -0.6447 at the $1 \%$ level, respectively. Meanwhile, the impact coefficients of both industrial structure upgrading (LIS) and technological innovation (LSTE) on carbon emissions were negative, -0.8110 and -0.0266 , and significant at the 10 and $1 \%$ levels, respectively, which is consistent with hypotheses one and two. These results verify that the mechanism through which land allocation impacts carbon emissions involves the hindering of industry structure upgrading and technological innovation.

\subsection{Robustness Test}

We demonstrated that our results were robust by analyzing the relationship between LRM and total carbon emissions. To further verify the robustness of the results on the impact of land resources on carbon emissions, the carbon emission intensity (LCI) was used as a substitute explanation variable. The regression results are shown in Table 7.

The estimated results for the fixed effect model were generally consistent with the above analysis. For the national model, the coefficient of LRM was 0.0330 and this was significant at the $1 \%$ level; that is, LRM by local governments also significantly increases the carbon emission intensity. In the sub-region model, the regression coefficients of LRM in the Eastern and Central regions were 0.0236 and 0.0215, respectively, and both of these results passed the significance test. The coefficient of LRM in the Western region (0.0272) was not significant. These results indicate that the local governments of the eastern and central regions have a more prominent "bottom line for attracting investment" effect. Moreover, the results for the significance and signs of the estimated coefficients of most control variables are basically consistent with the basic estimation results, verifying that the conclusions are reliable and stable. 
Table 7. Results for the impact of LRM on the carbon emission intensity.

\begin{tabular}{|c|c|c|c|c|}
\hline & $\begin{array}{l}\text { Nationwide } \\
\text { (FE) }\end{array}$ & $\begin{array}{c}\text { Eastern Regions } \\
\text { (FE) }\end{array}$ & $\begin{array}{c}\text { Central Regions } \\
\text { (FE) }\end{array}$ & $\begin{array}{c}\text { Western } \\
\text { Regions (FE) }\end{array}$ \\
\hline LRM & $\begin{array}{l}0.0330 * * * \\
(3.06)\end{array}$ & $\begin{array}{c}0.0236 * \\
(1.83)\end{array}$ & $\begin{array}{l}0.0215^{* *} \\
(2.51)\end{array}$ & $\begin{array}{l}0.0272 \\
(1.20)\end{array}$ \\
\hline LE & $\begin{array}{c}1.0145^{* *} \\
(2.38)\end{array}$ & $\begin{array}{c}4.1577^{* * *} \\
(5.84)\end{array}$ & $\begin{array}{c}4.1624^{* * *} \\
(7.17)\end{array}$ & $\begin{array}{c}-0.4755 \\
(-0.65)\end{array}$ \\
\hline $\mathrm{LE}^{2}$ & $\begin{array}{c}-0.0794^{* * *} \\
(-3.95)\end{array}$ & $\begin{array}{c}-0.2180^{* * *} \\
(-6.56)\end{array}$ & $\begin{array}{c}-0.2328^{* * *} \\
(-8.51)\end{array}$ & $\begin{array}{l}-0.0043 \\
(-0.12)\end{array}$ \\
\hline LP & $\begin{array}{l}-0.4824^{* *} \\
(-2.26)\end{array}$ & $\begin{array}{c}-0.2879 \\
(-1.1)\end{array}$ & $\begin{array}{l}-0.4346 \\
(-1.07)\end{array}$ & $\begin{array}{l}0.9142 \\
(1.59)\end{array}$ \\
\hline LURB & $\begin{array}{c}-0.5430 * * * \\
(-2.89)\end{array}$ & $\begin{array}{l}0.1980 \\
(0.63)\end{array}$ & $\begin{array}{c}-0.4826^{* * *} \\
(-3.37)\end{array}$ & $\begin{aligned}- & 2.4168^{* * *} \\
& (-5.54)\end{aligned}$ \\
\hline LIND & $\begin{array}{c}0.2380 * * * \\
(3.06)\end{array}$ & $\begin{array}{l}0.4653^{* * *} \\
(2.94)\end{array}$ & $\begin{array}{l}-0.0619 \\
(-1.09)\end{array}$ & $\begin{array}{c}0.2979 * \\
(1.69)\end{array}$ \\
\hline LNT & $\begin{array}{c}0.0111 \\
(0.41)\end{array}$ & $\begin{array}{l}-0.0430 \\
(-1.04)\end{array}$ & $\begin{array}{c}0.0742^{* * * *} \\
(3.09)\end{array}$ & $\begin{array}{l}0.0646 \\
(1.30)\end{array}$ \\
\hline LPFI & $\begin{array}{c}0.1072^{* *} \\
(2.57)\end{array}$ & $\begin{array}{l}-0.0150 \\
(-0.27)\end{array}$ & $\begin{array}{c}-0.1313^{* * *} \\
(-3.26)\end{array}$ & $\begin{array}{c}0.3086^{* * *} \\
(3.06)\end{array}$ \\
\hline LPFDI & $\begin{array}{c}-0.0574 * * * \\
(-4.78)\end{array}$ & $\begin{array}{c}-0.0529 * * \\
(-2.11)\end{array}$ & $\begin{array}{l}-0.0052 \\
(-0.25)\end{array}$ & $\begin{array}{l}-0.0018 \\
(-0.12)\end{array}$ \\
\hline $\mathrm{R}^{2}$ & 0.8854 & 0.9299 & 0.9818 & 0.8906 \\
\hline $\mathrm{F}$ & $301.44^{* * *}$ & $181.23^{* * *}$ & 521.82 *** & $111.23^{* * *}$ \\
\hline $\mathrm{N}$ & 390 & 143 & 104 & 143 \\
\hline
\end{tabular}

Note: the data in the table excluding parentheses are coefficients; $t$ values are presented in parentheses; ${ }^{*}, * *$, and *** represent significance at the 10,5, and 1\% levels, respectively; FE(RE) stands for fixed(random) effects model.

\section{Conclusions}

Total carbon emissions control is considered as a national strategy in China, and land resource allocation is the critical factor in the study of carbon emissions. Based on a theoretical analysis, this paper empirically tested the impact of LRM on carbon emissions using panel data from 30 provinces in China from the perspective of Chinese decentralization from 2005 to 2017. The results show the following: (1) The local governments' monopolization of the primary land market across the nation has resulted in LRM among industries and services. The inefficient and unsustainable allocation has aggravated the level and intensity of carbon emissions. (2) The impacts of LRM on carbon emissions have varied to some extent among different regions. LRM in the eastern and central regions has significantly exacerbated carbon emissions. More specifically, it has had a greater impact on carbon emissions in the eastern region, while it was shown to not obviously affect carbon emissions in the western region. (3) Based on the intermediary effect model, the intermediary mechanism through which LRM affects carbon emissions was found to be the restraint of industrial structure upgrading and technological innovation. Therefore, in summary, the serious misallocation of land resources among industries and services has strengthened the structural rigidity of medium- and low-end industries with high carbon emissions and hindered the enthusiasm of enterprises to undergo technological innovation under the Chinese decentralization system.

Based on this study, the following policy recommendations were concluded: (1) it is recommended that the fiscal and taxation system should be reformed to reduce the local governments' excessive dependence on land and to avoid excessive distortion of land resource allocation for economic growth. On the one hand, a fiscal and taxation system that matches the fiscal revenue power and responsibility of public affairs between the central government and local government should be developed; on the other hand, sustainable tax sources, such as real estate taxes, should be identified to fundamentally eliminate the excessive pursuit of land finance by local governments. (2) The performance appraisal system for local officials used in China should be improved. As Xia et al. pointed out, it should moderately reduce the weight of fiscal revenue and GDP assessment in areas with a fragile 
ecological environment, increase incentives for ecological environment protection, and put the development of the low-carbon economy into practice [78]. (3) The system of land expropriation and transfer should be reformed to gradually achieve a market-oriented land resource allocation model and improve the efficiency of land allocation and utilization. (4) Different carbon emission reduction policies should be formulated for the eastern, central, and western regions based on the heterogeneity of the regional economic development, industrial scale, technological level, and trade structure to promote regional low-carbon green development. The eastern region should optimize its land supply structure, change its economic growth mode, promote the transformation and upgrading of industrial structure, eliminate industries with high levels of energy consumption and pollution and low efficiency, and encourage technological innovation. The central and western regions should encourage urban agglomeration through increasing the urbanization rate, pay more attention to optimizing and adjusting the energy consumption structure, and vigorously promote the use of clean energy.

Author Contributions: Conceptualization, P.T. and A.M.; methodology, P.T. and Y.H.; software, Y.H.; validation, P.T., A.M., and Y.H; formal analysis, P.T. and Y.H.; investigation, P.T. and Y.H.; resources, P.T. and A.M.; data curation, Y.H.; writing — original draft preparation, P.T., A.M., and Y.H; writing-review and editing, P.T., A.M., and Y.H.; visualization, Y.H.; supervision, P.T. and A.M.; project administration, P.T. and A.M.; funding acquisition, P.T. and A.M. All authors have read and agreed to the published version of the manuscript.

Funding: This research was funded by the Humanities and Social Science Foundation of Ministry of Education of China (20YJA790051), Sichuan Funding of Social Sciences (SC20C011), and the Project of Sichuan University (2021CXC03, 2021DSDJ0010).

Institutional Review Board Statement: Not applicable.

Informed Consent Statement: Not applicable.

Data Availability Statement: Publicly available datasets were analyzed in this study. This data can be found here: http:/ / 182.150.59.104:8888/https/77726476706e69737468656265737421f4f6559d69336 65b774687a98c / Yearbook/Navi?type=type\&code=A, accessed on 1 November 2021.

Conflicts of Interest: The authors declare no conflict of interest.

\section{References}

1. IPCC. Summary for policymakers. In Climate Change: The Physical Science Basis; IPCC: Geneva, Switzerland, 2007.

2. Meinshausen, M.; Meinshausen, N.; Hare, W.; Raper, S.C.B.; Frieler, K.; Knutti, R.; Frame, D.J.; Allen, M.R. Greenhouse-gas emission targets for limiting global warming to $2{ }^{\circ} \mathrm{C}$. Nature 2009, 458, 1158-1162. [CrossRef]

3. Zhao, Y.; Huang, X.; Zhong, T.; Peng, J. Spatial pattern evolution of carbon emission intensity from energy consumption in China. Environ. Sci. 2011, 32, 3145-3152.

4. Liu, X.; Ou, J.; Wang, S.; Li, X.; Yan, Y.; Jiao, L.; Liu, Y. Estimating spatiotemporal variations of city-level energy-related CO2 emissions: An improved disaggregating model based on vegetation adjusted nighttime light data. J. Clean. Prod. 2018, 177, 101-114. [CrossRef]

5. Wang, S.; Liu, Y.; Fang, C. Review of energy-related CO2 emission in response to climate change. Prog. Geogr. 2015, 34, 151-164.

6. Chuai, X.; Lai, L.; Huang, X.; Zhao, R.; Wang, W.; Chen, Z. Temporal spatial changes of carbon footprint based on energy consumption in China. J. Geogr. Sci. 2012, 22, 110-124. [CrossRef]

7. Zhang, Y.; Peng, Y.; Ma, C.; Shen, B. Can environmental innovation facilitate carbon emissions reduction? Evidence from China. Energy Policy 2017, 100, 18-28. [CrossRef]

8. Du, L.; Wei, C.; Cai, S. Economic development and carbon dioxide emissions in China: Provincial panel data analysis. China Econ. Rev. 2012, 23, 371-384. [CrossRef]

9. Cheng, Y.; Wang, Z.; Ye, X.; Wei, Y.D. Spatiotemporal dynamics of carbon intensity from energy consumption in China. J. Geogr. Sci. 2014, 24, 631-650. [CrossRef]

10. Shi, K.; Yu, B.; Zhou, Y.; Chen, Y.; Yang, C.; Chen, Z.; Wu, J. Spatiotemporal variations of CO2 emissions and their impact factors in China: A comparative analysis between the provincial and prefectural levels. Appl. Energy 2019, 233-234, 170-181. [CrossRef]

11. Liu, Z.; Guan, D.; Crawford-Brown, D.; Zhang, Q.; Liu, J. A low-carbon road map for China. Nature 2013, 500, 143-145. [CrossRef] 
12. Wang, S.; Fang, C.; Guan, X.; Pang, B.; Ma, H. Urbanisation, energy consumption, and carbon dioxide emissions in China: A panel data analysis of China's provinces. Appl. Energy 2014, 136, 738-749. [CrossRef]

13. Zhang, H.; Zhang, X. Harmony of carbon trade and environmental protection restriction under Kyoto Protocol mechanism. J. Int. Trade 2005, 10, 107-111.

14. Wang, S. Influence mechanism and regional difference of new urbanization on carbon emission in China. Mod. Econ. Res. 2017, 7, 103-109.

15. Zhang, M.; Chen, Y.; Cheng, D.; Gan, C. Research on influences of land use structure and intensity change on carbon emissions. Resour. Dev. Mark. 2018, 34, 624-628, 675.

16. Klein, G.K.; Ramankutty, N. Land cover change over the last three centuries due to human activities: The availability of new global data sets. Geo J. 2004, 24, 335-344.

17. Yang, Y.; Xie, J.; Sheng, H.; Chen, G.; Li, X.; Yang, Z. The impact of land use/cover change on storage and quality of soil organic carbon in midsubtropical mountainous area of southern China. J. Geogr. Sci. 2009, 19, 49-57. [CrossRef]

18. Ge, Q.; Dai, J.; He, F.; Pan, Y.; Wang, M. Land use, land cover change and carbon cycle in China during the past 300 years. Sci. Sin. 2008, 2, 197-210.

19. Lai, L.; Huang, X.; Yang, H.; Chuai, X.; Zhang, M.; Zhong, T.; Chen, Z.; Chen, Y.; Wang, X.; Thompson, J.R. Carbon emissions from land-use change and management in China between 1990 and 2010. Sci. Adv. 2016, 2, 1601063. [CrossRef]

20. Jiang, Q.; Deng, X.; Zhan, J.; Liu, X. Impacts of cultivated land conversion on the vegetation carbon storage in the Huang-Hua-i Hai Plain. Geogr. Res. 2008, 4, 839-846, 975.

21. Zhao, R.; Huang, X.; Zhong, T.; Peng, J. Carbon footprint of different industrial spaces based on energy consumption in China. J. Geogr. Sci. 2011, 21, 285-300. [CrossRef]

22. Zhang, J.; Zhang, A.; Dong, J. Carbon emission effect of land use and influencing factors decomposition of carbon emission in Wuhan urban agglomeration. Resour. Environ. Yangtze Basin 2014, 23, 595-602.

23. Xu, Q.; Yang, R.; Dong, Y.; Liu, Y.; Qiu, L. The influence of rapid urbanization and land use changes on terrestrial carbon sources/sinks in Guangzhou, China. Ecol. Indic. 2016, 70, 304-316. [CrossRef]

24. Zhao, R.; Huang, X.; Zhong, T.; Chuai, X. Carbon effect evaluation and low-carbon optimization of regional land use. Trans. Chin. Soc. Agric. Eng. 2013, 29, 220-229.

25. Chuai, X.; Huang, X.; Wang, W.; Zhao, R.; Zhang, M.; Wu, C. Land use, total carbon emissions change and low carbon land management in Coastal Jiangsu, China. J. Clean. Prod. 2015, 103, 77-86. [CrossRef]

26. You, $\mathrm{H} . ; \mathrm{Wu}, \mathrm{C}$; Shen, P. Correlation degree measurement and characteristic explanation between land use structure and carbon emission from energy consumption. China Land Sci. 2010, 24, 4-9.

27. Tian, Y.; Li, B.; Zhang, J. Research on stage characteristics and factor decomposition of agricultural land carbon emission in China. J. China Univ. Geosci. (Soc. Sci. Ed.) 2011, 11, 59-63.

28. Zhao, R.; Huang, X.; Liu, Y.; Zhong, T.; Ding, M.; Chuai, X. Carbon emission of regional land use and its decomposition analysis: Case study of Nanjing city, China. Chin. Geogr. Sci. 2015, 25, 198-212. [CrossRef]

29. Tan, M.; Huang, X.; Zhong, T.; Zhao, R.; Gu, L.; Xu, Z.; Jiang, C.; Huang, J. Impacts of land consolidation on soil organic carbon content. Trans. Chin. Soc. Agric. Eng. 2011, 27, 324-329.

30. Guo, Y.; Yun, W.; Huang, N.; Liu, L. The effect of land consolidation projects on soil carbon emissions. Chin. J. Soil Sci. 2016, 47, 36-41.

31. Zhu, Q.; Mei, Y.; Chen, Y.; Han, X. Regional differentiation characteristics and optimization of the structural efficiency of land use in Hubei province based on the carbon emissions. Econ. Geogr. 2015, 35, 176-184.

32. Fan, J.; Yu, X.; Zhou, L. Carbon emission efficiency growth of land use structure and its spatial correlation: A case of Nanjing city. Geogr. Res. 2018, 37, 2177-2192.

33. Sun, X. Effects of carbon emission by land use patterns in Hefei's economic circle of Anhui province. J. Nat. Resour. 2012, 27, 394-401.

34. Cui, W.; Miao, J.; Lei, N. Analysis on spatial variation of the performance of urban non-agricultural land use in terms of carbon emission. China Land Sci. 2013, 27, 33-38.

35. Yu, Y.; Song, C.; Rong, K. Land resource misallocation and environmental pollution. Res. Financ. Econ. Issues 2018, 9, 43-51.

36. Huang, Z.; Du, X. Government intervention and land misallocation: Evidence from China. Cities 2017, 60, 323-332. [CrossRef]

37. Li, Y.; Luo, H. Does land resource misallocation hinder the upgrading of industrial structure? Empirical evidence from Chinese 35 large and medium-sized cities. J. Financ. Econ. 2017, 43, 110-121.

38. Li, Y. Does land resource misallocation hinder high-quality economic development? Empirical study based on 35 large and medium cities in China. Nanjing J. Soc. Sci. 2019, 10, 35-42.

39. Duan, L.; Chen, L.; Li, Y. Land resource misallocation and economic fluctuation: An empirical analysis based on prefecture-level city data in China. China Land Sci. 2019, 33, 64-72.

40. Xie, D. Land resource misallocation and city innovation capacity: Based on Chinese city-level panel data analysis. China J. Econ. 2020, 7, 86-112.

41. Jiang, S.; Liu, S.; Li, Q. Land system reform and national economic growth. Manag. World 2007, 9, 1-9.

42. Xu, C. The fundamental institutions of China's reforms and development. J. Econ. Lit. 2011, 49, 1076-1151. [CrossRef] 
43. Shao, C.; Su, D.; Deng, H. Housing price, land finance and city agglomeration characteristics: The road of China's city development. Manag. World 2016, 2, 19-31.

44. Tang, P.; Shi, X.; Gao, J.; Feng, S.; Qu, F. Demystifying the key for intoxicating land finance in China: An empirical study through the lens of government expenditure. Land Use Policy 2019, 85, 302-309. [CrossRef]

45. Xue, H.; Shi, X.; Tang, P. The impacts of Chinese decentralization on the deviation of land granting prices. Resour. Sci. 2013, 35, 1134-1142.

46. Tang, P.; Feng, Y.; Li, M.; Zhang, Y. Can the performance evaluation change from central government suppress illegal land use in local governments? A new interpretation of Chinese decentralisation. Land Use Policy 2021, 108, 1-12. [CrossRef]

47. Han, L.; James, K. Fiscal incentives and policy choices of local governments: Evidence from China. J. Dev. Econ. 2015, 116, 89-104. [CrossRef]

48. Zhang, J.; Fan, J.; Mo, J. Government intervention, land market, and urban development: Evidence from Chinese cities. Econ. Inq. 2017, 55, 115-136. [CrossRef]

49. Restuccia, D.; Rogerson, R. The causes and costs of misallocation. J. Econ. Perspect. 2017, 31, 157-174. [CrossRef]

50. Liu, Y.; He, S.; Wu, F.; Webster, C. Urban villages under China's rapid urbanization: Unregulated assets and transitional neighbourhoods. Habitat Int. 2010, 34, 135-144. [CrossRef]

51. Chen, T.; Kung, J.K.S. Do land revenue windfalls create a political resource curse? Evidence from China. J. Dev. Econ. 2016, 123, 86-106. [CrossRef]

52. Zhang, J.; Zhang, A. Benefit loss of land misallocation, and correction strategy in China. J. South China Agric. Univ. (Soc. Sci. Ed.) 2020, 19, 55-65.

53. Du, J.; Peiser, R.B. Land supply, pricing and local governments' land hoarding in China. Reg. Sci. Urban Econ. 2014, 48, 180-189. [CrossRef]

54. Wu, Y.; Zhang, X.; Skitmore, M.; Song, Y.; Hui, E.C.M. Industrial land price and its impact on urban growth: A Chinese case study. Land Use Policy 2014, 36, 199-209. [CrossRef]

55. Liu, Z. Function Transformation of industrial policy under the new normal of economic development. Nanjing J. Soc. Sci. 2015, 3, 33-41.

56. He, C.; Huang, Z.; Wang, R. Land use change and economic growth in urban China: A structural equation analysis. Urban Stud. 2014, 51, 2880-2898. [CrossRef]

57. Zhang, X.; Zhang, A.; Deng, C. Study on land resources distorted allocation and economic efficiency loss. China Popul. Resour. Environ. 2017, 27, 170-176.

58. Zhao, L.; Zhang, L.; Xu, L.; Hu, M. Mechanism of human capital, industrial structure adjustment and green development efficiency. China Popul. Resour. Environ. 2016, 26, 106-114.

59. Wang, X.; Duan, Y.; Liu, P.; Han, G. The influence of housing investment on urban innovation: An empirical analysis based on city-level panel data in Chia. Sustainability 2020, 12, 2968. [CrossRef]

60. Li, W.; Li, J. House price fluctuation, wage level and the mismatch of labor elements among regions. J. Zhongnan Univ. Econ. Law 2020, 2, 68-78, 159.

61. Li, X.; Zhao, X.; Yang, X. Does land finance drive up labor costs in China? China Land Sci. 2020, 34, 38-47.

62. Acemoglu, D. Training and innovation in an imperfect labour market. Rev. Econ. Stud. 1997, 64, 445-464. [CrossRef]

63. Wu, X.; Wang, M.; Li, L. Did high house price discourage entrepreneurship in China? Econ. Res. J. 2014, 49, 121-134.

64. Lu, Y.; Zhang, K.; Ou, Y. Does land finance hinder regional innovation? Based on the data of 267 prefectural-level city in China. J. Financ. Res. 2018, 5, 101-119.

65. Baumol, W.J. Entrepreneurship: Productive, unproductive, and destructive. J. Political Econ. 1990, 98, 893-921. [CrossRef]

66. Gerlagh, R. Measuring the value of induced technological change. Energy Policy 2007, 35, 5287-5297. [CrossRef]

67. Tu, Z.; Luo, Z. Strategic measures to reduce China's carbon emissions: Based on an index decomposition analysis of carbon emissions in eight industries. Soc. Sci. China 2014, 35, 158-173.

68. Grossman, G.M.; Krueger, A.B. Economic growth and the environment. Q. J. Econ. 1995, 110, 353-377. [CrossRef]

69. Li, L.; Huang, P.; Ma, G. Land resource misallocation and productivity difference of Chinese industrial enterprises. Manag. World 2016, 8, 86-96.

70. Deng, H.; Zhao, X.; Li, H. Optimized allocation of land resources and economic efficiency: Empirical evidence from a quasi-natural experiment of "area-based evaluation mechanism" reform in Zhejiang province. China Land Sci. 2020, 34, 32-42.

71. Zhang, S.; Yu, Y. Land lease, resource misallocation and total factor productivity. J. Financ. Econ. 2019, 45, 73-85.

72. Huang, Z.; Du, X. Review on the land resource misallocation studies. China Land Sci. 2014, 28, 80-87.

73. Zhang, M.; Peng, S.; Liu, X. A study on the mechanism of land misallocation hindering the new and old kinetic energy conversion. China Land Sci. 2020, 34, 95-102.

74. Yang, Q.; Zhuo, P.; Yang, J. Industrial land transfer and competition quality bottom line competition-based on the empirical study of panel data of prefecture-level cities in China from 2007 to 2011. Manag. World 2014, 11, 24-34.

75. Zhang, L. Relations among the industry structure, energy structure and carbon emissions. J. Arid. Land Resour. Environ. 2011, 25, $1-7$. 
76. Guo, B.; Lin, J. An empirical study on the impact of corruption on carbon dioxide emissions in China-Empirical evidence from provincial panel data. Soft Sci. 2017, 31, 59-62.

77. Chen, L.; Hu, L.; He, F. Factor flow, market integration and economic development-an empirical study based on Chinese provincial panel data. Inq. Econ. Issues 2019, 12, 56-69.

78. Xia, S.; You, D.; Tang, Z.; Yang, B.; Albulescu, C.; Pearce, J. Analysis of the Spatial Effect of Fiscal Decentralization and Environmental Decentralization on Carbon Emissions under the Pressure of Officials' Promotion. Energies 2021, $14,1878$. [CrossRef] 